\title{
Anadolu'ya Ait Yerel Mısır Popülasyonlarının Protein Bant Dizileri Yardımıyla Karakterizasyonu
}

\author{
Şule Akbulut $^{1 *}$ (iD) Fatih Kahrıman ${ }^{2}$ (iD) Cem Ömer Egesel ${ }^{3}$ iD \\ ${ }^{1}$ Çanakkale Onsekiz Mart Üniversitesi, Fen Bilimleri Enstitüsü, Tarımsal Biyoteknoloji Anabilim Dalı, Çanakkale/Türkiye \\ ${ }^{2}$ Çanakkale Onsekiz Mart Üniversitesi, Ziraat Fakültesi, Tarla Bitkileri Bölümü, Çanakkale/Türkiye \\ ${ }^{3}$ Çanakkale Onsekiz Mart Üniversitesi, Ziraat Fakültesi, Tarımsal Biyoteknoloji Bölümü, Çanakkale/Türkiye \\ *Sorumlu yazar: suleakbulut11@gmail.com
}

Geliş Tarihi: 23.07.2020

Kabul Tarihi: 31.05.2021

\section{$\ddot{O ̈ z}$}

Mısır (Zea mays) insan ve hayvan beslenmesinin yanı sıra endüstrinin çok farklı kollarında da geniş bir kullanım alanına sahip önemli bir tahıl türüdür. Mısır tanesinin kimyasal bileşiminin bir kısmını oluşturan protein miktarı çevresel ve genetik faktörler sonucu değişmekle birlikte ıslah çalışmaları yardımıyla ihtiyaca yönelik olarak modifikasyona tabi tutulabilir. Yerel misır popülasyonlarının protein miktarı ve protein fraksiyonları bakımından genetik çeşitliliğinin ve tanelerindeki kimyasal bileşimin değişkenliğinin saptanması oldukça önemlidir. Bu çalışmada yerel mısır popülasyonlarına ait 120 genotipte tanedeki albumin-globulin, glutelin ve zein içerikleri kantitatif olarak belirlenmiştir. Ayrıca, seçilen 30 genotipin SDS-PAGE analiziyle protein fraksiyonları moleküler ağırlıklarına göre tespit edilmiş ve kümeleme yöntemiyle istatistiksel olarak aralarındaki ilişkileri ortaya koyan bir dendrogram elde edilmiştir. SDS-PAGE analizi sonucu oluşan bantlar, albumin-globulin için 5-83 kDa arasında, glutelin için 9-71 kDa arasında, zein için 4-72 kDa arasında bulunmuştur. Protein fraksiyonları için kümeleme analizi ile oluşturulan akrabalık ağaçlarında genotipler ikişer ana grupta toplanmıştır. Kümeleme analizinin bir sonucu olarak, albumin-globulin için en benzer genotipler TR50515 ve TR38232 iken, zein ve glutelin için en benzer genotipler TR38451 ve TR44385'tir. Elde edilen veriler sonucu yerel mısır popülasyonlarının oldukça geniş bir varyasyona sahip olduğu ortaya koyulmuş ve farklı protein kalite özelliklerine sahip çeşitlerin geliştirilmesi için yürütülecek ıslah çalışmalarında kullanılabilecek genotipler tespit edilmiştir.

Anahtar kelimeler: Misır, Albumin-globulin, Zein, Glutelin

\section{Characterization of Anatolian Maize Landraces by Protein Band Sequences Abstract}

Maize (Zea mays) is an important cereal species that has a wide application in many different industries along with its global use as food and feed. Although the ratio of protein, which forms part of the chemical composition of maize grain, changes due to environmental and genetic factors, it can be modified according to needs with the help of breeding studies. Determining the genetic variability of landraces and the variation of chemical compounds in the grain are of importance for breeding purposes. In this study, the contents of albuminglobulin, glutelin and zein in corn grains of 120 genotypes belonging to local maize populations were determined quantitatively. Additionally, protein fractions of 30 selected genotypes were classified according to their molecular weights by SDS-PAGE analysis, and a dendrogram was obtained to show the statistical relationships among them through the clustering method. The bands formed by SDS-PAGE analysis were between $5-83 \mathrm{kDa}$ for albumin-globulin, 9-71 kDa for glutelin, and 4-72 kDa for zein. Genotypes were collected in two main groups in similarity trees created by cluster analysis for protein fractions. As a result of the cluster analysis, the most similar genotypes for albumin-globulin were TR50515 and TR38232, while the most similar genotypes for zein and glutelin were TR38451 and TR44385. It has been revealed that the local maize populations have a quite wide variation and the genotypes that can be used in breeding studies to develop varieties with different protein qualities have been identified.

Keywords: Maize, Albumin-globulin, Zein, Glutelin

\section{Giriş}

Mısır genetik değişkenliği oldukça geniş olan bir bitki olmakla beraber, tropikal, subtropikal ve 1lıman tarımsal bölgeleri kapsayan çok çeşitli çevresel koşullar üzerinde dünya çapında başarıyla yetiştirilmektedir. Tek yıllık bir C4 bitkisi olması nedeniyle fizyolojik olarak verimli olmasının yanı 
sıra farklı çevrelere adaptasyonu da üst seviyededir. Son zamanlarda modern dünyanın yaygın kullanılan gıda bitkisi ve çok yönlü kullanılan en önemli tahıllardan biri haline gelmiştir. İnsan beslenmesinde buğday ve çeltikten sonra en çok kullanılan bitkidir (Özcan, 2009; Patel ve ark., 2018).

İnsan beslenmesinde mısır önemli bir protein kaynağıdır, ancak esansiyel amino asitlerin, özellikle lizin ve triptofanın düşük miktarda bulunması nedeniyle düşük protein kalitesine sahiptir (Shewry, 2007). Misır tohumları \%8-10 protein içerir ve bunların \%70'i depo proteinleri olarak sınıflandırılır. Farklı kimyasal ortamlardaki çözünürlüklerine göre, endosperm proteinleri albuminler, globulinler, glutelinler ve prolaminler olarak dört gruba ayrilır (Flint-Garcia ve ark., 2009; Wu ve Messing, 2014). Bu gruplardan albumin ve globulinler tuzlu su ortamında, glutelinler asit ortamda ve zeinler ise alkolde çözünen bileşenlerdir. Ayrıca glutelinler moleküler ağırlıklarına göre genellikle yüksek moleküler ağırlıklı (HMW-GS; 80-120 kDa) ve düşük moleküler ağırlıklı (LMW-GS; 30-80 $\mathrm{kDa}$ ) olarak 2 gruba ayrilır (Galova ve ark., 2011).

Misir tanesinin protein kalitesi tohum endosperminde oldukça fazla bulunan prolaminlere (zeinlere) bağlıdır. SDS-PAGE yöntemiyle tanımlanan zeinler çözünürlükleri ile yapısal ilişkilerine göre $\alpha$-zeinler (22 ve $19 \mathrm{kDa})$, z-zeinler $(15 \mathrm{kDa}), \gamma$-zeinler $(27,16$ ve $50 \mathrm{kDa})$ ve $\delta$-zeinler $(10$ ve 18 $\mathrm{kDa}$ ) olarak 4 farklı sınıfa ayrılırlar (Spalekova ve ark., 2019). Zeinler dışındaki tüm fraksiyonlar amino asit içeriği bakımından dengelidir ve lizin ile triptofan bakımından oldukça zengindir. Diğer proteinlerin oranını büyük ölçüde değiştirmeden lizin eksikliği olan DNA fraksiyonunun baskılanması, mısır tanesinde amino asit dengesinde iyileşme sağlamak için uygulanabilir bir yaklaşım olarak görülebilir (Priya ve ark., 2014). Şimdiye kadar mısırda protein kalitesinin düzelmesi, endosperm modifikasyonlarının yanı sıra kaliteli protein mısırının (QPM) gelişmesine yol açan resesif opak2 (o2) mutantı sayesinde olmuştur. Homozigot $o 2$ mutantı, endospermde zein miktarında bir azalmaya ve doğal olarak daha yüksek seviyelerde lizin ve triptofan içeren, zein dışındaki diğer proteinlerin oranında bir artışa neden olmaktadır (Gibbon ve Larkins 2005). Nitekim mısırda protein kalitesinin iyileştirilmesi esansiyel amino asitlerin artırılmasına yönelik bir sslah stratejisi ile mümkündür (Prasanna ve ark., 2001). Bu nedenle protein kalitesi yüksek mısırların geliştirilmesine olanak sağlayabilecek genetik kaynakların taranması ve ümitvar olanların belirlenmesi zorunlu hale gelmiştir (Pfunde ve ark., 2015)

Birim alan veriminde hibrit çeşitler ve modern tarım teknolojileri sayesinde oldukça önemli artışlar meydana gelmiştir. Mısırın 2007 yılında dünyadaki üretimi 792 milyon 732 bin ton iken, 2019'da 1,149 milyar tona çıkmıştır (Özcan, 2009; Anonim, 2020). Türkiye'de ise 2020 yılında mısır bitkisinin ekiliş alanı 692 bin hektar ve üretim miktarı 6,5 milyon ton'dur (Anonim, 2021). Verimin yanı sıra mısırda kalite özelliklerinin geliştirilmesi birçok ıslah programının hedefleri arasındadır (Egesel ve Kahrıman, 2012). Mısırın çok yönlü kullanım alanına sahip olması bu bitki ile ilgili yapılacak çalışmalara duyulan ihtiyacı artırmaktadır. Yerel popülasyonlar, çevre ile birlikte sürekli evrimleştiklerinden yerel popülasyonların bulunduğu mısır tarlaları, hibrit çeşitlerin verimlerinin artırılması, hastalıklara ve diğer stres faktörlerine karşı dayanıklılık açısından performansını iyileştirmek için kullanılabilecek yeni yararlı alellerin potansiyel kaynağını oluşturmaktadırlar (Shanbao ve ark., 2009). Yerel popülasyonların metabolik özelliklerinin bilinmesi ekonomik değerlerinin de artırılmasına katkı sağlayabilmek için oldukça önemli bir adımdır (Uarrota ve ark., 2011). İstenen özellik bakımından üstün genotiplerle ilgili 1slah çalışmaları yapmak için genetik çeşitlilik esastır. Genetik çeşitliliğin belirlenmesi ve genotip tanımlamada moleküler belirteçlerin uygulanması, seleksiyon etkinliğini artırarak ıslah programlarını da hızlandırmaktadır (Agarwal ve ark., 2008; Muhammad ve ark., 2017). Mısır genetik kaynaklarının SDS-PAGE yöntemi ile genetik çeşitliliğinin belirlenmesi amacıyla farklı ülkelerin yerel mısır genotipleri üzerinde çeşitli araştırmalar yürütülmüştür (Vivodik ve ark., 2016; Spalekova ve ark., 2019). Türk yerel mısırlarına yönelik bu yöntem ile bazı araştırmalar yapılmış olsa da (Ünlü ve ark., 2018) bu genetik kaynaklarda protein fraksiyonlarının kantitatif ve kalitatif varyasyonları ile ilgili kapsamlı araştırmalara ihtiyaç vardır.

Bu çalışmanın amacı Türkiye'nin farklı yörelerinden toplanmış yerel mısır popülasyonlarının protein oranı ve protein fraksiyonları bakımından mevcut varyasyonunu incelemek ve bu bileşenler bakımından farklı değerlere sahip (yüksek, orta, düşük) popülasyonların SDS-PAGE yöntemi ile genetik yakınlıklarını araştırmaktır. Ayrıca incelenen protein fraksiyonlarının kalıtımına ilişkin değerlendirmeler ile ileride bu materyallerden hangi alanlarda faydalanabileceğinin belirlenmesi hedeflenmiştir. 


\section{Materyal Yöntem}

\section{Bitkisel Materyal}

Bu çalışmada Karadeniz, Marmara, Ege, Güney Doğu Anadolu, Akdeniz, Doğu Anadolu bölgelerindeki at dişi ve sert tane yapısına sahip köy popülasyonlarından farklı sayılarda alınan 120 genotip kullanılmıştır. Standart çeşit olarak ise yedi adet ticari hibrit çeşit kullanılmıştır. Kullanılan yüz yirmi genotip içerisinden protein ekstraksiyonu sonrası belirlenen albumin-globulin, glutelin ve zein miktarılarına bakılarak her bir özellik için düşük, orta ve yüksek değerlere sahip 10'ar (toplam 30) genotip seçilmiş ve SDS-PAGE analizinde kullanılmıştır.

\section{Protein Ekstraksiyonu}

Misır endosperminde bulunan protein fraksiyonları için sırasıyla; albumin-globulin için $0,5 \mathrm{~N}$ $\mathrm{NaCl}$ solüsyonu, glutelin için $\% 70$ etanol ve $\% 2$ B- merkaptoetanol, zein için $\% 1$ SDS ve $\% 2 \beta-$ merkaptoetanol solüsyonları hazırlanmıştır. Yağdan ve nemden uzaklaştırılan endosperm unları eppendorf tüplerin içine $100 \mathrm{mg}$ olacak şekilde hassas terazide tartılarak koyulmuştur. Tüplerin içindeki örneklerin üzerine hazırlanan ekstraksiyon tamponları sırasıyla eklenerek 1 saat boyunca çalkalayıcı yardımıyla çalkalanmış ve iki kez ekstrakte edilmiştir. Albumin ve globulinler $4{ }^{\circ} \mathrm{C}$ 'de, zein ve glutelin ise $22{ }^{\circ} \mathrm{C}$ 'de ekstrakt edilmiştir. Numunenin ve ekstraksiyon tamponunun karışımları 10.000 g'de 10 dakika süreyle santrifüje tabi tutulmuştur. Aynı fraksiyondan gelen süpernatantlar toplanmış ve boya bağlama yöntemi ile konsantrasyonlar için ölçülmüştür. Zeinler ve glutelinler, referans olarak zein kullanılarak albumin ve globulinler, referans olarak albumin kullanılarak Bradford protein testi ile ölçülmüştür. Tüm bu işlemlerin devamında üst fazlardan alınan her bir fraksiyonun supernatantlarından elde edilen ekstaktlardan $5 \mu 1$ alınarak üzerine $200 \mu 1$ Bradford solüsyonu eklenmiş ve mikroplaka içindeki haznelere koyularak mikroplaka okuyucuda $595 \mathrm{~nm}$ 'de absorbans değerleri kayıt altına alınmıștır.

\section{SDS-PAGE}

Sodyum Dodesil Sülfat varlığında Poli Akrilamid Jel Elektroforezi için öncelikle gerekli solüsyonlar hazırlanmıştır.

\%10'luk Amonyum persülfat: $1 \mathrm{~g}$ amonyum persülfat $10 \mathrm{ml}$ saf su içerisinde çözdürülerek hazırlanmıştır.

Stacking jel solüsyonu (4X): $60,5 \mathrm{~g}$ tris base $850 \mathrm{ml}$ saf su içerisinde çözdürülerek ve $\mathrm{pH}{ }^{1}$ $\mathrm{HCl}$ ile 6,8 'e ayarlandıktan sonra son hacim 1000 ml'ye tamamlanmıştır.

$\% 30$ 'luk Acrylamide solüsyonu: 29,22 g acrylamide ve 0,78 g bisacrylamide $100 \mathrm{ml}$ saf su içerisinde çözdürülmüştür.

Resolving jel solüsyonu (4X): $181,5 \mathrm{~g}$ tris base $850 \mathrm{ml}$ saf su içerisinde çözdürülerek ve $\mathrm{pH}$ $\mathrm{HCl}$ ile 8,8'e ayarlandıktan sonra son hacim 1000 ml'ye tamamlanmıştır.

10X Running buffer: $30 \mathrm{~g}$ tris base, $144 \mathrm{~g}$ glisin ve $10 \mathrm{~g}$ SDS tartılarak $1000 \mathrm{ml}$ saf su içerisinde çözdürlür. Her kullanım için $500 \mathrm{ml}$ running buffer ve $4500 \mathrm{ml}$ saf su karıştırılmış ve elektroforez tank1 5 litre running buffer ile doldurulmuştur.

Stok 4X yükleme tamponu: $4 \mathrm{ml}$ gliserol, $2 \mathrm{ml}$ mercaptoethanol, 1,2 g SDS, $5 \mathrm{ml} 4 \mathrm{X}$ stacking solüsyonu, $0,03 \mathrm{~g}$ bromofenol karıştırılmış ve $-20^{\circ} \mathrm{C}$ 'de saklanmıştır.

Santrifüjde ekstrakte ettiğimiz örneklerin üst fazından aldığımız süpernatantlardan elde edilen kısımdan $250 \mu \mathrm{L}$ alınmıştır. Albumin-globulinler için \%15'lik çözücü jel ve tankın üst kısmına eklenecek olan \%4'lük ayırma jeli hazırlanmıştır. Zeinler için ise \%12'lik çözücü jel hazırlanmıştır. Elektroforez tankının içinde iki ayrı jel koşturması için her birinden 2 jel karışımı hazırlanmıştır.

Çizelge 1. Elektroforez için gerekli jellerin hazırlanmasında kullanılan solüsyonlar

\begin{tabular}{|c|c|c|}
\hline \%4'lük Ayırma Jeli & \%12’lik Çözücü Jel (Zeinler için) & \%15'lik Çözücü Jel \\
\hline $\begin{array}{ll}\text { - } & 16,8 \mathrm{ml} \text { saf su } \\
\text { - } & 2,6 \mathrm{ml} \% 30 \text { acrylamyde } \\
& \text { solüsyonu } \\
\text { - } & 6,4 \mathrm{ml} 4 \mathrm{X} \text { stacking jel, Tris } \\
& \text { solüsyonu } \\
\text { - } & 0,01 \mu \mathrm{L} \% 10 \text { amonyum } \\
& \text { persülfat } \\
\text { - } & 26,8 \mu \mathrm{L} \mathrm{TEMED}\end{array}$ & $\begin{array}{ll}\text { - } & 12,35 \mathrm{ml} \text { saf su } \\
\text { - } & 14,1 \mathrm{ml} \% 30 ’ l u k \text { stok acrylamyde } \\
& \text { solüsyonu } \\
\text { - } & 18,8 \mathrm{ml} 4 \mathrm{X} \text { çözücü Tris solüsyonu } \\
\text { - } & 350 \mu \mathrm{L} \% 10^{\prime} l u k \text { amonyum } \\
& \text { persülfat } \\
\text { - } & 35 \mu \mathrm{L} \text { TEMED }\end{array}$ & $\begin{array}{ll}\text { - } & 8,8 \mathrm{ml} \text { saf su } \\
\text { - } & 17,625 \mathrm{ml} \% 30 \text { acrylamide } \\
& \text { solüsyonu } \\
\text { - } & 18,8 \mathrm{ml} 4 \mathrm{X} \text { çözücü Tris } \\
& \text { solüsyonu } \\
\text { - } & 350 \mu \mathrm{L} \% 10 \text { 'luk amonyum } \\
& \text { persülfat } \\
\text { - } & 35 \mu \mathrm{L} \text { TEMED }\end{array}$ \\
\hline
\end{tabular}




\section{Örneklerin Dikey Elektroforezde Koşturulması}

Elektroforez tankının içine \%15'lik albumin veya glutelinler için hazırlanan çözücü jel ve ardından üzerine \%4'lük ayrıcı jel dökülmüştür (her jelin katılaşması için 30 dakika beklenmiştir). Zeinler için ise yalnızca \%12'lik jel dökülmüştür. Üzerine $250 \mu \mathrm{L}$ yükleme tamponu konulan örnekler vorteks yardımıyla çalkalanmış ve $95{ }^{\circ} \mathrm{C}$ 'de 5 dakika boyunca sıcak su banyosunda bekletildikten sonra 3000 g'de santrifüj edilmişlerdir. 96 kuyucuklu mikroplatelere ilk kuyucuk boş bırakılarak, ikinci kuyucuğa $8 \mu \mathrm{L}$ standart ve üçüncü kuyucuktan itibaren $8 \mu \mathrm{L}$ örnek yüklenmiştir. Örnekler 100 V'da tam ayrım gerçekleşene kadar koşturulmuşlardır. Daha sonra jel tankından alınan jeller, 60 gr TCA, 1 gr Brilliant Blue ve $25 \mathrm{~mL}$ etanolün saf suyla $500 \mathrm{~mL}$ 'ye tamamlanan karışım solüsyonuyla gece boyunca çalkalayıcıya bırakılmış ve ardından jellerin görüntüsü kaydedilerek Gelanalyzer programına yüklenmiştir. İlk ve son kuyucuklara koyulan standartların oluşturduğu 9 bant belirlenerek moleküler ağırlıkları 10,15, 25, 35, 55, 70, 100, 130, $250 \mathrm{kDa}$ olarak programa tanımlanmıştır. Moleküler ağırlıkları tanımlanan standartlara göre oluşan diğer örneklerin oluşturduğu bantların moleküler ağırlıkları program tarafından hesaplanmıştır.

\section{Verilerin Değerlendirilmesi}

Tarla denemesi augmented deneme desenine göre kurulup 2018 yılında Çanakkale şartlarında yürütülmüştür. Çalışmadan elde edilen verilerin istatistiksel olarak değerlendirilmesinde augmented deneme desenine uygun varyans analizi tekniği kullanılmıştır. Verilerin analizinde R-Project (R Core Team, 2018) programının 'augmentedRCBD' kütüphanesinden (Aravind ve ark., 2019) yararlanılmıştır. Yüz yirmi yedi genotip tarlada bulundukları yere göre 6 bloğa, standart çeşitler ve köy popülasyonları olmak üzere iki gruba ayrılmışlardır.

\section{Bulgular ve Tartışma}

Genotiplerin albumin-globulin, glutelin ve zein içerikleri önce kantitatif olarak belirlenmiştir.

Çizelge 2. Protein fraksiyonlarına ait varyans analizi tablosu

\begin{tabular}{rrrrrrrr}
\hline Varyans Kaynağı & SD & & A-G & & Glutelin & & Zein \\
\hline & & KO & P değeri & KO & P değeri & KO & P değeri \\
Standartlar & 6 & 0,028 & 0,974 & 0,163 & 0,065 & 0,457 & 0,341 \\
Genotip (BH) & 126 & 0,144 & 0,499 & 0,078 & 0,423 & 0,676 & 0,044 \\
Grup & 1 & 0,982 & 0,013 & 0,470 & 0,016 & 0,133 & 0,560 \\
Popülasyon & 119 & 0,143 & 0,510 & 0,070 & 0,562 & 0,662 & 0,038 \\
Blok (GH) & 5 & 0,061 & 0,823 & 0,013 & 0,968 & 2,14 & 0,0009 \\
Hata & 30 & 0,142 & & 0,072 & & 0,386 & \\
\hline
\end{tabular}

*SD: serbestlik derecesi, A-G: Albumin-Globulin, GH: genotip etkisi hariç, BH: blok etkisi hariç, KO: kareler ortalamas1

Varyans analizi sonuçları standart çeşitler ile köy popülasyonları arasında albumin-globulin ve glutelin içeriği bakımından önemli bir fark olduğunu ( $\mathrm{p}=0,013)$ göstermiş, zein içeriği bakımından köy popülasyonlarına ait genotiplerin varyasyona etkisi önemli bulunmuştur $(\mathrm{p}=0,044)$ (Çizelge 2$)$.

Yerel mısır popülasyonlarının albumin-globulin değerleri \%0,06 ile \%2,10 arasında değişmiş, ortalama albumin-globulin oranı \%1,14 olarak belirlenmiştir. Standart çeşitlerin albumin-globulin oranlarına bakıldığında değer aralığı \%0,87-\%1,07, ortalama ise $\% 0,96$ olarak tespit edilmiştir. Glutelin oranları köy popülasyonlarında \%0,87-2,23, standart çeşitlerde \%1,56-1,99 arasında değişmektedir. Popülasyonlara ait ortalama değer \%1,62, standartlara ait ortalama değer ise \%1,7 olarak belirlenmiştir. Hem albumin-globulin hem de glutelin oranları bakımından grup içi farklılıklar istatistiki olarak önemli bulunmamış olmasına karşın sahip olunan aralıklar aslında göz ardı edilemeyecek bir varyasyonun mevcut olduğunu göstermektedir. Genotiplerin ortalama zein oranı $\% 1,89$ bulunmuş, ayrıca \%0,09 ile zein oranı en düşük olan genotip Ege bölgesinden, \%3,95 ile en yüksek zein oranına sahip genotip Karadeniz bölgesinden toplanan materyallerdendir. Ortalama \%1,6 zein içeren standart çeşitlerin sahip olduğu varyasyonun istatistiki olarak önemli çıkmadığ görülmektedir. Endosperm depo proteinlerinin normal misır tanesindeki proteinde ortalama olarak; albuminlerin $\% 3$ oranında, globulinlerin $\% 3$ oranında, zeinlerin $\% 60$ oranında ve glutelinlerin $\% 34$ oranında bulunduğu farklı çalışmalarda bildirilmiştir (Flint-Garcia ve ark., 2009; Priya ve ark., 2014; Yau ve ark., 1999; Wu ve Messing, 2014). Bunun dışında Mısır Araştırma Enstitüsü Zemun Polje (MRIZP), Belgrad, Sırbistan'da geliştirilen sekiz mısır melezinin tane özelliklerini karakerize etmek 
amacıyla yapılan çalışmada kuru madde miktarında ortalama olarak albumin \%1,71 oranında, globulin $\% 1,10$ oranında, $\alpha$-zein \%2,67 oranında, glutelin \%2,23 oranında bulunmuştur (Zilic ve ark., 2011). Literatürde yer alan bu çalışmalara bakıldığında bizim çalışmamızdaki genotiplerde zein oranının biraz daha düşük, glutelin oranının orta seviyede, albumin-globulin oranının ise yüksek olduğu sonucuna varılabilir.

Protein fraksiyonlarının geniş anlamda kalıtım dereceleri albumin-globulin için 0,024 , glutelin için 0,024 ve zein için 0,440 olarak bulunmuştur. Robinson (1966) tarafından yapılan değerlendirmeye göre, albumin-globulin ve glutelin bileşenlerine ait kalıtım dereceleri düşük $(<0,30)$, zeine ait kalıtım derecesi ise orta seviyededir $(0,30 \leq$ ile $<0,60)$. Protein fraksiyonlarının kantitatif analiz sonuçlarına göre köy popülasyonları içerisinde zein, glutelin, ve albumin içeriğine göre ayrı ayrı olmak üzere 3'er adet düşük, 4'er adet orta ve 3'er adet yüksek değere sahip 10'ar adet (toplamda 30 adet) genotipin SDS-PAGE yöntemine göre jel görüntüleri Şekil 1, Şekil 2 ve Şekil 3 'te gösterilmiştir. Albuminglobulin için yapılan SDS-PAGE analizi sonucu toplam 51 bant belirlenmiştir. $7 \mathrm{kDa}$ moleküler ağırlığına sahip bant 15 genotipte görülürken, $22 \mathrm{kDa}$ moleküler ağırlığındaki bant 21 genotipte gözlemlenmiştir (Şekil 1). Yau ve ark. (1999) tarafından albumin globulin için yapılan çalışmada SDS-PAGE sonucu oluşan bantların 5-54 kDa arasında değiştiği bulunmuştur. Bizim çalışmamızda neredeyse benzer bir sonuç bulunmuş, albumin-globulin açısından genotiplerin 5-83 kDa arasında değiştiği belirlenmiştir.
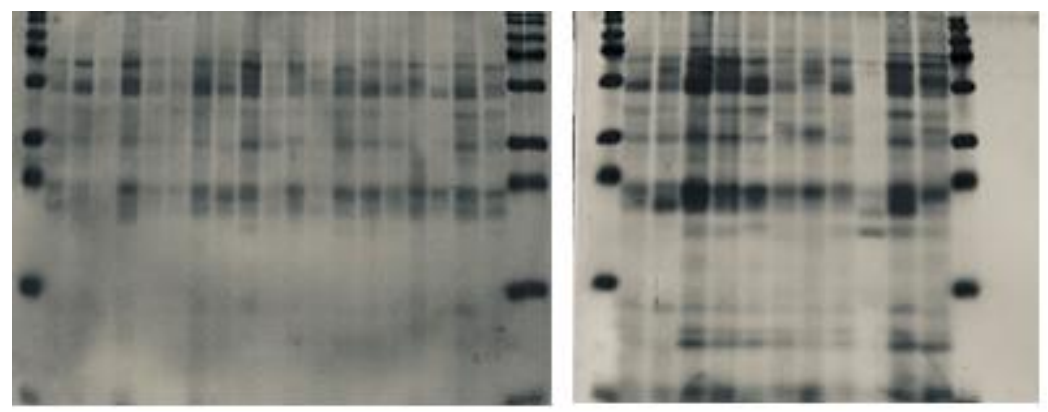

Şekil 1. Albumin-Globulin için yapılan SDS-PAGE analizi sonucu genotiplerin jel görüntüleri (İlk ve son kuyucuklarda yukarıdan aşağıya $250 \mathrm{kDa}, 130 \mathrm{kDa}, 100 \mathrm{kDa}, 70 \mathrm{kDa}, 55 \mathrm{kDa}, 35 \mathrm{kDa}, 25 \mathrm{kDa}, 15 \mathrm{kDa}$ ve 10 kDa moleküler ağırlığa sahip standartlar bulunmaktadır).

Glutelin için SDS-PAGE'de 47 bant gözlemlenmiş, 12 kDa moleküler ağırlığına sahip bant 19 genotipte, $13 \mathrm{kDa}$ moleküler ağırlığa sahip bant 20 genotipte, $15 \mathrm{kDa}$ moleküler ağırlığa sahip bant 22 genotipte, $19 \mathrm{kDa}$ moleküler ağırlığa sahip bant 21 genotipte ve $21 \mathrm{kDa}$ moleküler ağırlığa sahip bant 21 genotipte gözlemlenmiştir. Oluşan bantlar 9-71 kDa arasındadır (Şekil 2). Glutelinlerin moleküler ağırlıklarına göre genellikle yüksek moleküler ağırlıklı glutelin alt birimleri (HMW-GS; 80-120 kDa) ve düşük moleküler ağırlıklı glutelin alt birimleri (LMW-GS; 30-80 kDa) olarak 2 gruba ayrıldığı bildirilmiştir (Galova ve ark., 2011). Çalışmamızda SDS-PAGE yöntemiyle belirlenen glutelinlere ait bant dizilerinin tamamının $80 \mathrm{kDa}$ 'nın altında olduğu görülmektedir. Bu durumda yaptığımız analiz sonucu yalnızca düşük moleküler ağırlıklı glutelinlerin belirlendiği söylenebilir.

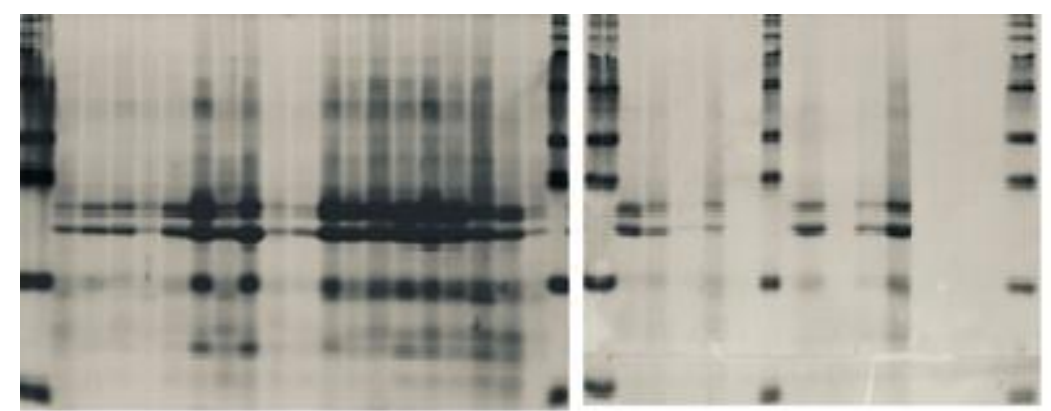

Şekil 2. Glutelin için yapılan SDS-PAGE analizi sonucu genotiplerin jel görüntüleri (İlk ve son kuyucuklarda yukarıdan aşağıya $250 \mathrm{kDa}, 130 \mathrm{kDa}, 100 \mathrm{kDa}, 70 \mathrm{kDa}, 55 \mathrm{kDa}, 35 \mathrm{kDa}, 25 \mathrm{kDa}, 15 \mathrm{kDa}$ ve $10 \mathrm{kDa}$ moleküler ağırlığa sahip standartlar bulunmaktadır). 

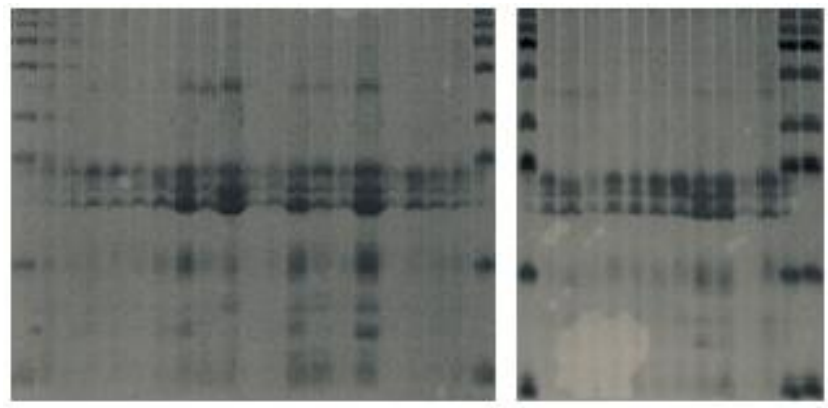

Şekil 3. Zein için yapılan SDS-PAGE analizi sonucu genotiplerin jel görüntüleri (İlk ve son kuyucuklarda yukarıdan aşağıya $250 \mathrm{kDa}, 130 \mathrm{kDa}, 100 \mathrm{kDa}, 70 \mathrm{kDa}, 55 \mathrm{kDa}, 35 \mathrm{kDa}, 25 \mathrm{kDa}, 15 \mathrm{kDa}$ ve $10 \mathrm{kDa}$ moleküler ağırlığa sahip standartlar bulunmaktadır).

Zein fraksiyonları bakımından SDS-PAGE analizi sonucu farklı moleküler ağırlıklarda 28 adet bant oluşturduğu gözlenmiş, bu bantlardan 19-24 arası moleküler ağırlığa sahip olanlar bütün genotiplerde gözlemlenirken oluşan diğer bantlar polimorfizm göstermiştir. Zein fraksiyonlarına yönelik analizde oluşan bantlar 4-72 kDa arasındadır (Şekil 3). SDS-PAGE yöntemiyle tanımlanan farklı moleküler ağırlıktaki zeinlerin ise, $\alpha$-zeinler (22 ve $19 \mathrm{kDa})$, z-zeinler $(15 \mathrm{kDa}), \gamma$-zeinler $(27,16$ ve $50 \mathrm{kDa}$ ) ve $\delta$-zeinler (10 ve $18 \mathrm{kDa}$ ) olarak sınıflandırıldığ çalışmalarda raporlanmıştır (Spalekova ve ark., 2019). Yaptığımız SDS-PAGE analizi sonucu özellikle 22-19 kDa bantların genotiplerin çoğunda görüldügüü gözlemlenmiştir. Genotiplerin \%22'sinde 10-18 kDa olan bantlar bulunmakta, $\% 27$ 'sinde $10 \mathrm{kDa}$ olan bant bulunmaktadır.

Spalekova ve ark. (2019) kümeleme analizi yöntemi kullanılarak 30 çeşit mısır arasındaki ilişkileri ortaya koymak için bir dendrogram oluşturmuş ve çeşitlerin 2 ana kümeye ayrıldığını bildirmişlerdir. SDS-PAGE ile elde ettikleri protein bantlarının boyutu, 5 ila $120 \mathrm{kDa}$ arasında değişmiştir. Vivodik ve ark. (2016), Avrupa'ya ait 40 mısır genotipinde 23 protein bandı belirlerken, bu bantların moleküler ağırlıkları ise 20 ila $140 \mathrm{kDa}$ arasında değişmiştir. Yapılan bu çalışmalara bakıldığında, bizim çalışmamızda da benzer bir şekilde belirlenen bant aralığının 4-131 kDa arasında olduğu görülmektedir fakat çalışmamızda belirlenen bant sayısı bu çalışmalara göre çok daha fazladır.

Elde edilen jel görüntülerinin sayısal skorlara dönüştürülmesinin ardından bu skorlara göre oluşturulan kümeleme dendrogramları Şekil 4'te sunulmuştur. Oluşturulan dendrogramların her biri 8 ve 22 genotip olmak üzere 2 ana kümeye ayrılmış ve ikinci büyük kümedeki 22 genotip de eşit bir şekilde kendi içinde iki gruba ayrılmıştır. Dendrogramların hepsinde ilk kümede 23, 24, 25, 26, 27, 28 , 29, 30 nolu genotipler (TR37630, TR48893, TR51719, TR51727, TR38040, TR37583, TR55471, TR55540) bulunurken diğer genotipler ikinci kümede yer almıştır. Protein bantlarının varlığı/yokluğu bakımından en benzer genotipler 22 genotip içeren ikinci kümede bulunmaktadır. Hem glutelin hem de zein bakımından birbirine en benzeyen iki genotip 5 ve 6 nolu genotipler (TR38451 ve TR44385) olurken, albumin-globulin bakımından birbirine en fazla benzerlik gösteren genotipler ise 12 (TR50515) ile 15 (TR38323) olmuştur (Şekil 4). Genotiplerin hepsi, üç dendrogramda da aynı kümelerde bulunurken yalnızca 15 numaralı genotip, glutelin için oluşturulan dendrogramda farklı bir kümede yer almıştır. Bu durumda genotiplerin her üç özellik bakımından da benzer ilişkilere sahip olduğu görülmektedir. 


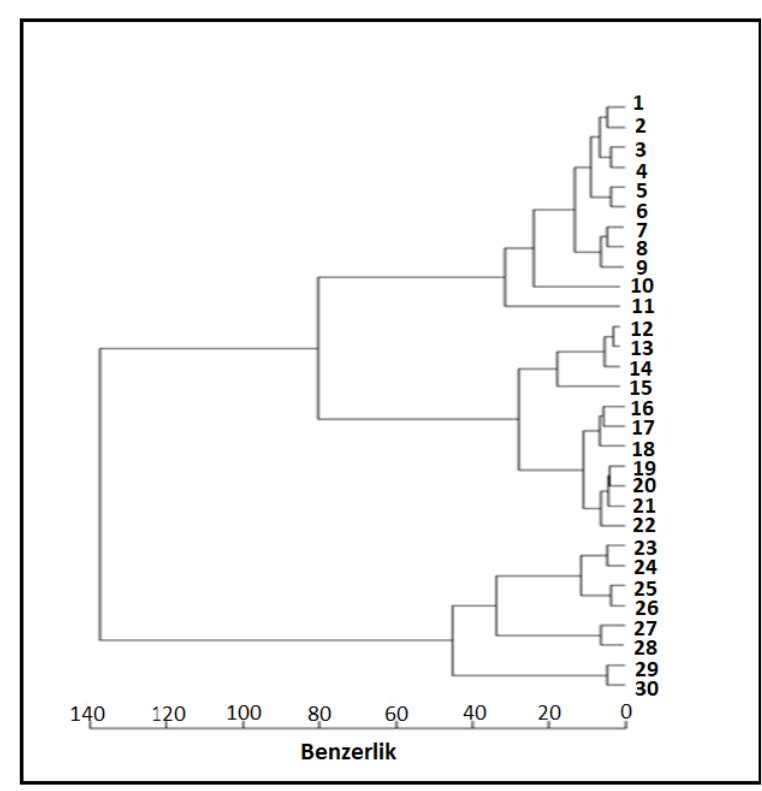

(A)

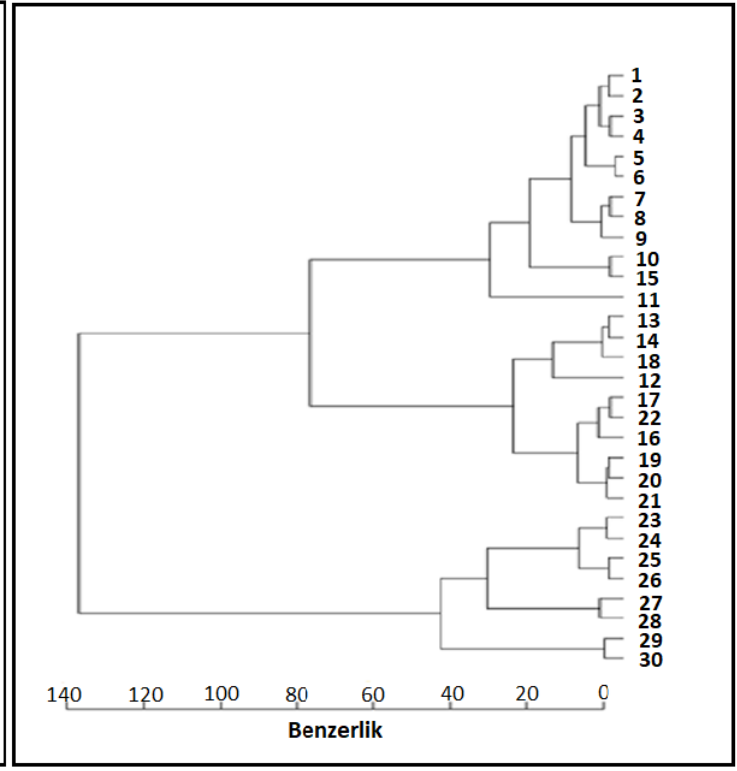

(B)

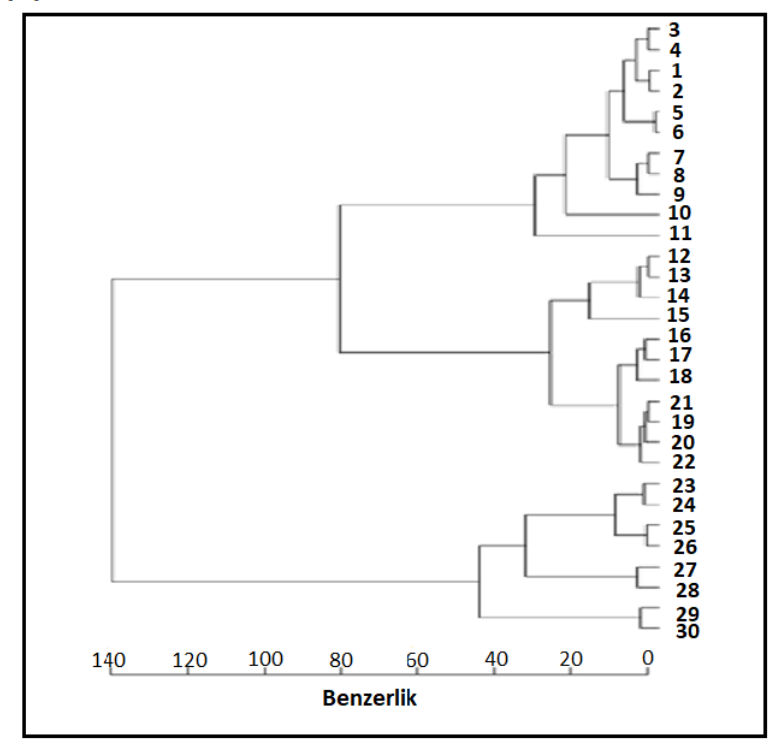

(c)

Şekil 4. Genotipler arasındaki ilişkileri gösteren dendrogramlar (A- albumin-globulin bakımından, B- glutelin bakımından, C- zein bakımından aralarındaki ilişkiler). TR54196, TR53254, TR37998, TR37115, TR38451, TR44385, TR50551, TR42948, TR49234, TR38208, TR42868, TR50515, TR38323, TR42985, TR50642, TR42725, TR38401, TR37573, TR50511, TR50130, TR37876, TR49303, TR37630, TR48893, TR51719, TR51727, TR38040, TR37583, TR55471, TR55540 kodlu genotipler sirasiyla 1'den 30'a kadar numaralandırılmıştır.

\section{Sonuç ve Öneriler}

Lizin ve triptofan miktarının az olmasından zeinlerin sorumlu olduğu bilindiğinden kantitatif analiz sonucu belirlenen zein içeriği en düşük olan TR37955, TR55507, TR50511, TR37986, TR50130, TR38323 kodlu genotipler QPM ıslah çalışmalarında değerlendirilebilir.

Otuz genotip için yapılan SDS-PAGE sonucu albumin-globulin bakımından en benzer genotipler 12 (TR50515) ve 15 (TR39323) numaralı genotiplerdir ve ikisi de Karadeniz bölgesine aittir. Hem glutelin hem de zein bakımından en benzer genotipler 5 (TR38451) ve 6 (TR44385) numaralı genotipleridir. Bu genotiplerden ilki Ege bölgesine ait ikincisi ise Karadeniz bölgesinden toplanmış materyallerdir. Anadolu'daki popülasyonlar protein fraksiyonları bakımından oldukça geniş bir varyasyona sahip olmakla birlikte, farklı bölgelerde olsalar dahi aralarında akrabalık ilişkileri 
bulunabileceği söylenebilir. Zein bakımından köy popülasyonlarının göstermiş olduğu genetik varyasyon ve bu özellik ile ilgili olarak tespit edilen kalıtım derecesinin boyutu ıslah açısından ümitvar olarak değerlendirilebilir.

Not: Bu makale Şule Akbulut'un “Anadolu’ya Ait Yerel Mısır Popülasyonlarının Protein Bant Dizileri Yardımıyla Karakterizasyonu” adlı yüksek lisans çalışmasına dayanılarak hazırlanmıştır.

\section{Teşekkür}

$\mathrm{Bu}$ araştırma Çanakkale Onsekiz Mart Üniversitesi Bilimsel Araştırmalar Projeleri Başkanlığı tarafindan FYL2019-2821 numaralı proje olarak desteklenmiştir.

\section{Kaynaklar}

Agarwal, M., Shrivastava, N., Padh, H., 2008. Advances in molecular marker techniques and their applications in plant sciences. Plant Cell Reports. 27: 617-631.

Anonim, 2020. Food and Agriculture Organization of the United Nations, http://faostat.fao.org/faostat (Erişim tarihi: 27.05.2021)

Anonim, 2021. Türkiye İstatistik Kurumu Sitesi. http://tuik.gov.tr (Erişim tarihi: 27.05.2021).

Aravind, J., Mukesh Sankar, S., Wankhede, D. P., Kaur, V., 2019. AugmentedRCBD: Analysis of augmented randomised complete block designs. R package version 0.1.1.

Egesel, C. Ö., Kahrıman, F., 2012. Determination of quality parameters in maize by NIR reflectance spectroscopy. Journal of Agricultural Sicences. 18:43-53.

Flint-Garcia, S. A., Bodnar, A. L., Scott, M. P., 2009. Wide variability in kernel composition, seed characteristics, and zein profiles among diverse maize inbreds, landraces, and teosinte. Theoretical and Applied Genetics. 119: 1129-1142.

Galova, Z., Balazova, Z., Chnapek, M., Vivodik, M., Oslovicova, V., 2011. Bielkovinové a DNA markery pšenice. Nitra: Slovak University of Agriculture.

Gibbon, B. C., Larkins, B. A., 2005. Molecular genetic approaches to developing quality protein maize. Trends in Genetics. 21: 227-233.

Muhammad, R.W., Qayyum, A., Ahmad, M.Q., Hamza, A., Yousaf, M., Ahmad, B., Younas, M., Malik, W., Liagat, S., Noor, E., 2017 Characterization of maize genotypes for genetic diversity on the basis of inter simple sequence repeats. Genetics and Molecular Research. 16 (1).

Özcan, S., 2009. Modern dünyanın vazgeçilmez bitkisi mısır: genetiği değiştirilmiş (transgenik) mısırın tarımsal üretime katkısı. Türk Bilimsel Derlemeler Dergisi. 2(2): 01-34.

Patel, P. C., Kathiria, K. B., Patel, B. N., Dave, P. B., Soni, N. V., 2018. Study of genetic architecture through haymen's graphical approach for quantitative and qualitative traits in quality protein maize (Zea mays L.) over environments. Electronic Journal of Plant Breeding. 9(4): 1476-1483.

Pfunde, C. N., Mutengwa, C. S., Bradley, G., 2015. Genetic variation of selected quality protein maize inbred lines. African Journal of Agricultural Research. 10(44): 4087-4093.

Prasanna, B., Vasal, S., Kassahun, B., Singh, N., 2001. Quality protein maize. Current Science. 81(10): 13081319.

Priya, D., Ram, L., Srivastava, R. P., Kumar, A., Singh, R., 2014. Quality protein maize: Overview. Journal of Biotechnology and Crop Science. 3(3): 4-18, 2014.

R Core Team, 2018 R: A language and environment for statistical computing. R Foundation for Statistical Computing, Vienna, Austria.

Robinson, H. F., 1966. Quantitative genetics in relation to breeding on centennial of Mendelism. Indian Journal of Genetics and Plant Breeding. pp.171.

Shanbao, Q., Yuhua, W., Tingzhao, R., Kecheng, Y., Shibin G., Guangtang, P., 2009. Effective improvement of genetic variation in maize lines derived from R08xDonor backcrosses by SSRs. Biotechnology. 8: 358364.

Shewry, P. R., 2007. Improving the protein content and composition of cereal grain. Journal of Cereal Science. 46 (3): 239-250.

Spalekova, A., Gregova, E., Galova, Z., 2019. Electrophoretic profiles of storage proteins in selected maize (Zea mays L.) genotypes. Journal of Central European Agriculture. 20(3): 911-918.

Uarrota, V. G., Schmidt, C. E., Bouzon, Z. L., Maraschin, M., 2011. Histochemical Analysis and Protein Content of Maize Landraces (Zea mays L.). Journal of Agronomy. 10: 92-98.

Ünlü E., Mutlu E., Polat M., Çeri S., Kahriman F., 2018. Diversity among Turkish maize landraces based on protein band analyses and kernel biochemical properties. Journal of Crop Improvement. 32:175-187.

Vivodik, M., Galova, Z., Balazova, Z., Petrovicova, L., Hlozakova, T.K., 2016. Genetic variation and relationships of old maize genotypes (Zea mays L.) detected using SDS-page. Potravinarstvo Slovak 
ÇOMÜ Zir. Fak. Derg. (COMU J. Agric. Fac.)

2021: 9 (1): 79-87

ISSN: 2147-8384 / e-ISSN: 2564-6826

doi: $10.33202 /$ comuagri.772844

Journal of Food Sciences. 10(1): 532-536.

$\mathrm{Wu}$, Y., Messing, J., 2014. Proteome balancing of the maize seed for higher nutritional value. Frontiers in Plant Science. 5: 240.

Yau, J. C., Bockholt, A. J., Smith, J. D., Rooney, L. D., Waniska, R. D., 1999. Maize endosprem protein that contribute to endosperm lysine content. American Association of Cereal Chemists. 76(5): 668-672.

Zilic, S., Milasinovic, M., Terzic, D., Barac, M., Ignjatovic-Micic, D., 2011. Grain characteristics and composition of maize specialty hybrids. Spanish Journal of Agricultural Research. 9(1): 230-241. 